Thorax (1969), 24, 472.

\title{
Bronchial carcinoma in a young Negro
}

\author{
P. H. K I D NER A N D H. O. W I L L I A M S \\ From King's College Hospital, London S.E.5, and Islington Chest Clinic, Whittington Hospital, London N.19 \\ A case of bronchial carcinoma occurring in a young Negro is described. The incidence of the \\ condition in the Negro race is reviewed. Although it is apparently rare in the native African, it is \\ much more common in the American of Negro stock. Two factors are suggested as being respon- \\ sible for this-increasing longevity and increasing contact with external carcinogens, of which \\ the most likely is cigarette smoke. Available evidence indicates that the disease is, as yet, rare in \\ the British Negro but may be expected to rise following the pattern in the United States.
}

The following case of bronchial carcinoma in a young Nigerian presented a difficult diagnostic problem and, in the light of subsequent inquiry into the incidence of lung cancer in people of negro origin, was considered worth reporting.

\section{CASE HISTORY}

F. A., a 27-year-old Nigerian law student, was first seen in February 1965. He had been in England for six years. He complained of lassitude for two to three months, and of three weeks' pain in the right lower chest, aching in nature. He had no other symptoms.

B.C.G. vaccination had been given in Nigeria in 1956. There was no recent history of contact with tuberculosis, and no recent chest radiograph had been taken. There was nothing relevant in his past or family history. He had smoked about 10 cigarettes a day for several years.

When first seen he looked well. He was afebrile. There was no finger clubbing and no abnormally enlarged lymph nodes. The breath sounds over the chest were vesicular and there were no adventitious sounds. The cardiovascular system was normal, the B.P. $120 / 80 \mathrm{~mm}$. Hg. Examination of the abdomen and central nervous system was also normal.

A chest radiograph showed an enlarged right hilar shadow with right mid and lower zone shadowing. These appearances were thought to be due to a pneumonia and out-patient treatment with tetracycline, $250 \mathrm{mg}$. six-hourly, was given for one week. There was no clinical nor radiological improvement and the patient was admitted.

There were no acid-fast bacilli, no secondary organisms, and no pus cells in the sputum, but many epithelial cells were seen. The Mantoux test was positive at 1 in 1,000 dilution, E.S.R. $25 \mathrm{~mm}$. in one hour (Westergren), $\mathrm{Hb} 86 \%$, and the white cell count 4,700 per cu. mm. with a normal differential count. The sick- ling test was positive and paper electrophoresis showed the presence of haemoglobins $A$ and $S$. The patieng was pyrexial to $99 \cdot 2^{\circ} \mathrm{F}$. Treatment with ampicillin, $1 \mathrm{~g}$. six-hourly, was started. He continued to have ato intermittent pyrexia reaching $100 \cdot 6^{\circ} \mathrm{F}$. By the sixtl day the chest radiograph showed a little further righ lower zone shadowing.

With the lack of response to antibiotics, the swing ing pyrexia, the strongly positive Mantoux test, and the above radiological appearances, the diagnosis oథ pulmonary tuberculosis was considered likely. therapeutic trial was made of streptomycin, 1 g., P.A.S 12 g., and isoniazid, $300 \mathrm{mg}$. daily. Despite this treat? ment the patient's temperature continued to react evening levels of $101-102^{\circ}$ F., accompanied bø? drenching night sweats, malaise, and weakness Streptomycin was discontinued because of giddiness $\ddot{\phi}$ viomycin, 1 g. i.m.i. three times weekly was sub $\underline{3}$. stituted.

Because of the continued fever, prednisone, $10 \mathrm{mg}$ b.d., was commenced. This temporarily reduced the pyrexia. Two days later the patient complained of severe pain in the right shoulder and arm, and the right arm became swollen due to thrombosis of the right axillary vein. Anticoagulation was commenced with heparin and phenindione.

One week later the patient complained of pains in both lower limbs and examination revealed superfician thromboses in both calves. The following day he suddenly became breathless. A firm, tender, right supraclavicular swelling was now evident and believee to be an extension of the axillary vein thrombosi $\$$ into the subclavian vein. The patient was shocked with the pulse rate at 140 per minute. There was no rise in the jugular venous pressure, B.P. $150 / 80 \mathrm{~mm}$ $\mathrm{Hg}$. There was a right ventricular heave over the praeg cordium and an ejection systolic murmur at the apexp The respiratory rate was above 30 per minute. TherE were physical signs of collapse and effusion over the right lung. Obvious tenderness was elicited on pa局 
pation of the upper abdomen and both calves. An electrocardiogram showed an $\mathrm{S}_{1} \mathrm{Q}_{3} \mathrm{~T}_{3}$ pattern with inverted $T$ waves in leads $V_{1-3}$. The radiograph showed extensive mottling throughout the right lung field with areas of collapse, consolidation, and effusion present in the right mid and lower zones. The hilar shadows were enlarged.

A sickle cell crisis was diagnosed, complicated by pulmonary emboli. Intravenous magnesium and bicarbonate therapy was instituted with temporary improvement. The steroids were discontinued.

The right supraclavicular swelling was increasing in size, and in addition to the venous thromboses enlarged right cervical and left axillary lymph nodes were palpated. A pleural biopsy was performed with aspiration of $10 \mathrm{ml}$. slightly bloodstained fluid. The patient's condition was poor, and when on the same day a sudden haemoptysis occurred, he was transferred to University College Hospital with a view to hyperbaric oxygen therapy in an attempt to prevent further sickling and embolization. The pleural biopsy subsequently proved unhelpful, but microscopy of the pleural fluid showed large primitive cells, single and in clumps. Many mitoses 'strongly suggestive of a rapidly growing malignant tumour' were seen.

Biopsy of the enlarged cervical nodes at University College Hospital revealed anaplastic tumour. Despite radiotherapy and mustine he went rapidly downhill and died early in April 1965. The duration of the acute illness had been nine weeks.

A limited necropsy was allowed. This showed a small blcodstained pericardial effusion and an infiltrating tumour around the aorta. There was adherent thrombosis in the left and right iliac veins; $600 \mathrm{ml}$. of bloodstained effusion was present in the right pleural cavity, and $700 \mathrm{ml}$. in the left. The left pleura was studded with small tumour deposits and there was an old infarct in the left lower lobe distal to adherent thrombus. There was a necrotic tumour laterally in the right lower lobe, at the periphery, with lymphatic permeation of the lung substance and gross involvement of the mediastinal nodes. The liver showed one secondary deposit, $1 \mathrm{~cm}$. in diameter, and eight other minute ones. Apart from extensive carcinoma in the para-aortic nodes, examination of the other systems was normal. Histology of the tumour was reported as showing a poorly differentiated squamous-cell carcinoma.

\section{DISCUSSION}

The course of this patient's illness was complicated by the development of deep venous thromboses and a pulmonary embolus. Bronchial carcinoma remained unsuspected until too late and a fatal termination was inevitable. Two other factors adding difficulty to the diagnosis were the patient's youthfulness and his nationality. Research into the records of bronchial neoplasm at the Islington
Chest Clinic revealed that there had been only one other case in a person of Negro stock. All the chest clinics in the North-West Metropolitan Region were contacted. Information was obtained concerning only five other cases. These are not intended to give an accurate idea of the incidence of bronchial carcinoma in the Negro population of the region, but they do serve to indicate its present rarity. In the same region, in one year (1966) the number of registrations of carcinoma of the lung was 2,524 in a population of 4.21 million. Unfortunately, a racial incidence of the condition is not available either in the North-West Metropolitan area or in Great Britain as a whole, and there is no accurate census of the Negro population. At present, Negro immigrants to this country appear to be in the younger age groups, and the proportion of Negro to white population is relatively low. These are likely to be factors contributing to the infrequent observation of bronchial carcinoma in British persons of Negro origin. It is not known whether the low incidence of the condition in this racial group is apparent or real, or whether it may be expected to increase with the passage of time and the change of environment brought about by immigration.

It was decided to investigate the frequency of lung cancer in Negro populations elsewhere in the world.

Difficulty exists in evaluating the incidence of bronchial carcinoma in the African continent. Accurate census figures are not available. Those that do exist, relating to malignancy, report the incidence in areas immediately surrounding townships and do not necessarily include figures for that occurring in the 'bush'. Moreover, the population around townships may be considered a selected sample and is frequently changing. Nevertheless, reports have emerged from different parts of the continent which give some idea of the extent to which bronchial carcinoma affects the Negro.

Linsell and Martyn reviewed the Kenya Cancer Registry in 1962. Comparison was made between Kenya, Ghana, Nigeria, and Uganda. The incidence of bronchial neoplasm was reported as $0.3-$ $1.0 \%$ of all neoplasms diagnosed. At the same time Briggs (1960) reported the results of a mass miniature radiographical survey in the territory then known as Northern Rhodesia in 1957-8 and found no bronchial neoplasms in 30,239 natives examined. He was impressed by the absence of serious non-tuberculous disease of the chest.

The reported incidence of bronchial carcinoma is higher in some areas of the African continent. Rouan and Leproux (1961) quoted the incidence in 
Negroes in Dakar as 2.5 per 100,000 , that is, six to seven times less common than in the indigenous white population. They stated that there was no difference in the presentation and histology between the two groups but that carcinoma of the bronchus appeared to be more common in those Africans whose way of life was similar to that of the European population. This impression appears to be supported by the review of bronchial carcinoma in the three racial types in South Africa, namely, whites of European descent, Cape Coloureds, and Bantu, carried out by Uys and Perold (1963). They point out that Cape Coloureds are of mixed European, Hottentot, and Malay stock and are more European than African in their way of life. In 270 cases of primary bronchial carcinoma examined in the Pathology Department of the University of Cape Town between 1950 and 1960, 168 cases occurred in Europeans, 92 in Cape Coloureds, and only 10 cases in the native Bantu.

It should be added, however, that in the period 1950 to 1960 , Bantu admissions to the Cape Town Hospital were only one-fifth of the total, while the proportion of Europeans to Cape Coloureds admitted was about equal. Moreover, of necropsies on subjects who had died over the age of 40 years, $55 \%$ were white, $35 \%$ were Cape Coloureds, and only $10 \%$ Bantu. Thus the low rate of bronchial carcinoma observed in the Bantu does not necessarily indicate a low incidence of the condition in that race.

A recent review of tumours comes from Ross (1967) at Harare Hospital in Salisbury, Rhodesia. In this hospital in the period 1955-65, some 4,124 malignancies were found in the Mashonaland African. Of these, 146 were carcinomata of the lung, an incidence of about $3.5 \%$ of all tumours seen. This is a somewhat higher incidence than that mentioned above. Tulloch (1963) reported a series from Bulawayo in 1957 in which the incidence of lung carcinoma was $8 \cdot 6 \%$. Most of these cases were derived from the Gwanda area of Matabeleland, an area in which carcinoma of the bronchus is peculiarly high, some 14 cases coming to necropsy out of a total of 34 neoplasms so examined in the period 1948-53. Osburn (1957) attributed this high incidence to employment of these Africans in local mines, the ore from which had a high arsenic content. This factor may or may not have been of significance. He noted also that 11 out of 11 patients so questioned smoked. However, mines often have very good medical services and any increase in observed incidence may be due to better diagnostic facilities.
One of the most recent and reliable studies of carcinoma of the bronchus and the smoking hab in Rhodesian Africans was published by Gelfand? Graham, and Lightman (1968). They compared the smoking habits of 32 adult male Rhodesia $\mathbb{D}$ Africans, who had proved carcinoma of the bronchus, with controls of the same age, sex, and background. The results showed that $87.5 \%$ of the patients with lung cancer were cigarette smoker compared with only $22 \%$ of the controls, a highle significant result under the conditions of the tria: It was pointed out that atmospheric pollution could not be regarded a factor in Rhodesian towns or, indeed, in any part of Central Africa.

Davies, Wilson, and Knowelden (1962) have commented upon the absence of carcinogens in tho African environment. When comparison is made between cancer incidence and age, the incidence rises in a parallel manner up to the age of 50 years in U.S. white and non-white, in Norwegians, an in Johannesburg Bantu and Kyadondo Africare? Whereas the incidence rises steeply after 50 years in the American and Norwegian, the incidence is the Kyadondo flattens off, and that of the Bant climbs less steeply. It is suggested that this finding aids the hypothesis that external carcinogens pla a part in the increased incidence of neoplasm with age in urbanized areas. This supports Osburn views, already mentioned, together with those of Gelfand and others and Rouan and Leproux, whe noted that one factor in the process of 'Europeanization' was the acquisition of the smoking habi

In Volume 1 of Carcinoma of the Lung, edite by Bignall, Doll (1958) has pointed out that the latent period between the first exposure to the hazard and the appearance of lung cancer has been long. While individual cases have occurre after as little as five years and as much as 50 yeare from the first exposure, the usual period has bee 15 to 30 years. In the same volume, Case (195\& showed in his tables of Age-Specific Death Ratês for Cancer of the Lungs, England and Wales, 1911-1955, that the majority of lung canced deaths in males and females occurred after the age of 40 years. Related to these observationsthe life-expectancy of the African Negro should be considered. In many of the recently indeperf dent African countries, where the population almost entirely Negro, available figures indicat that the exprectation of life seldom exceeds 46 years, but in Rhodesia and South Africa (Table the figures indicate an improvement in the liffe expectancy of the Negro inhabitant. In other countries relevant to the present discussion, the trend is toward increasing longevity the more developed 
T A B L E

EXPECTATION OF LIFE AT BIRTH FOR EACH SEX, UNITED NATIONS DEMOGRAPHIC YEARBOOK, 1966(TAKEN FROM LIFE TABLES)

\begin{tabular}{|c|c|c|c|c|}
\hline \multirow{2}{*}{ Country } & \multicolumn{3}{|c|}{$\begin{array}{l}\text { Expectation of Life at Birth } \\
\text { (Years) }\end{array}$} & \multirow{2}{*}{$\begin{array}{c}\text { Latest } \\
\text { Available } \\
\text { Year }\end{array}$} \\
\hline & Male & Female & $\begin{array}{l}\text { Both } \\
\text { Sexes }\end{array}$ & \\
\hline $\begin{array}{l}\text { Kenya } \\
\text { Zambia } \\
\text { S. Rhodesia }\end{array}$ & & & $\begin{array}{l}40-45 \\
40\end{array}$ & $\begin{array}{l}1962 \\
1963\end{array}$ \\
\hline $\begin{array}{l}\text { African population } \\
\text { European population } \\
\text { S. Africa }\end{array}$ & 66.9 & $74 \cdot 0$ & 50 & $\begin{array}{l}1962 \\
1961-63\end{array}$ \\
\hline $\begin{array}{l}\text { Coloured population } \\
\text { (Negro) }\end{array}$ & $44 \cdot 82$ & $47 \cdot 77$ & & $1950-52$ \\
\hline $\begin{array}{l}\text { Asiatic population } \\
\text { (Cape coloured) }\end{array}$ & $55 \cdot 77$ & $54 \cdot 75$ & & $1950-52$ \\
\hline $\begin{array}{l}\text { White population } \\
\text { Jamaica } \\
\text { Trinidad } \\
\text { U.S.A. } \\
\text { U.K. }\end{array}$ & $\begin{array}{l}64 \cdot 57 \\
62 \cdot 65 \\
62 \cdot 15 \\
66 \cdot 8 \\
68 \cdot 3\end{array}$ & $\begin{array}{l}70 \cdot 08 \\
66 \cdot 63 \\
66 \cdot 33 \\
73 \cdot 7 \\
74 \cdot 4\end{array}$ & & $\begin{array}{l}1950-52 \\
1959-61 \\
1959-61 \\
1965 \\
1963-65\end{array}$ \\
\hline
\end{tabular}

the country and the more the Negro becomes an urban dweller.

Bras, Watler, and Ashmeade-Dyer (1965) reported on the Cancer Registry in Jamaica in 1965. This covered the population of Kingston and St. Andrew, some 420,000 people or $20 \%$ of the total Jamaican population, comprising $65 \%$ negroes and $30 \%$ of mixed racial origin. This report spanned the years 1958-63, when 2,989 malignant neoplasms were found. Included in these were 107 cases of bronchial carcinoma, 83 in men and 24 in women, an overall incidence of $3.7 \%$. This is four times higher than the incidence of $0.3-1.0 \%$ reported from the Kenya Cancer Registry.

It is possible to compare the incidence of bronchial carcinoma in the United States of America for the years 1950 and 1964. In that time the incidence rose from $12 \cdot 2$ per 100,000 of the population in 1950 to 24.0 per 100,000 in 1964 . The incidence ratio of 'whites' to 'non-whites' in 1950 was $1 \cdot 7: 1$ and in 1964 it was $1 \cdot 4: 1$. Thus, not only was the incidence of bronchial carcinoma in the population as a whole increasing, but it was increasing at a more rapid rate in the 'non-white' sector, and this comprised $90 \%$ Negroes. In 1950 the cigarette consumption for each adult per year was 3,250 . The figure for 1962, the latest year for which figures were available, was 3,900 . It is interesting to speculate on the cause and effect relationship between the rise in cigarette consumption and the increase of bronchial carcinoma. Unfortunately, it is not known whether the Negro's consumption of cigarettes increased during this period, though it seems probable that it did.

The available evidence indicates that the comparatively low incidence of bronchial carcinoma in negroes in the developing countries is likely to increase if they emigrate and settle in the more economically developed countries. Two main factors would appear to play a part, namely, the improved expectation of life and greater exposure to external carcinogens, of which the chief is cigarette smoke.

We should like to thank Dr. J. Wallace Craig, Physician-in-Charge, Islington Chest Clinic, for permission to publish this case.

We are grateful to Mrs. M. O. Halls and Miss M. Howell for clerical assistance.

\section{REFERENCES}

Bras, G., Watler, D. C., and Ashmeade-Dyer, A. (1965). The incidence of malignant neoplasms in Jamaica. Brit. J. Cancer, 19, 681 .

Briggs, I. L. (1960). A mass miniature radiography and tuberculintesting survey in African miners and their dependents on the copperbelt of N. Rhodesia, 1957-58. Cen. Afr. J. Med., 6, 6.

Case, R. A. M. (1958). In Neoplastic Disease at Various Sites: Carcinoma of the Lung, Vol. I, ed. J. R. Bignall, pp. 13-14, Livingstone, Edinburgh and London.

Davies, J. N. P., Wilson, B. A., and Knowelden, J. (1962). Cancer incidence of the African population of Kyadondo (Ugand a) Lancet, $2,328$.

Doll, R. (1958). In Carcinoma of the Lung, ed. J. R. Bignall, p. 58 Livingstone, Edinburgh and London.

Gelfand, M., Graham, A. J. P., and Lightman, E. (1968). Carcinoma of bronchus and the smoking habit in Rhodesian Africans. Brit. med. J., 3, 468 .

Linsell, C. A., and Martyn, R. (1962). The Kenya Cancer Registry. E. Afr. med. J., 39, 642 .

National Center for Health Statistics, U.S.A. Report 1950-64.

North West Metropolitan Regional Hospital Board. Cancer Registration Bureau. (Personal communication, June 1968.)

Osburn, H. S. (1957). Cancer of the lung in Gwanda. Cen. Afr. J. Med., 3, 215.

Ross, M. D. (1967). Tumours in Mashonaland Africans. Ibid., 13, 107.

Rouan, M., and Leproux, P. (1961). La place du carcinome bronchique dans la cancérologie en afrique Noire. J. franc. Méd. Chir. thor., 15, 601 .

Tulloch, B. S. (1963). M.D. Thesis, University of St. Andrews.

United Nations (1967). Demographic Yearbook 1966, pp. 562-583. New York.

Uys, C. J., and Perold, J. I. (1963). Bronchogenic carcinoma: The distribution of histological types in the three racial types of Cape Town. S. Afr. med. J., 37, 828. 